DEPARTMENT OF THI INTERTon

Ray Lyman Wibur, Secretary

U. \$. GEOLOGICAL BUEVET George Otis Smith Direetar

Professional Paper 158-F

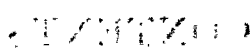

\title{
CONTACT METAMORPHISM OF THE ROCKS IN THE PEND OREILLE DISTRICT, NORTHERN ID AHO
}

$+$

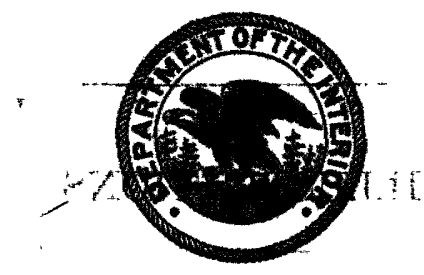
. . " t.

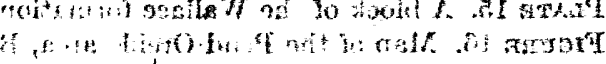

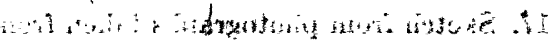
BY

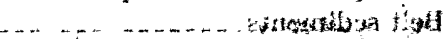
............ :

JOSEPH L. GLLLSON

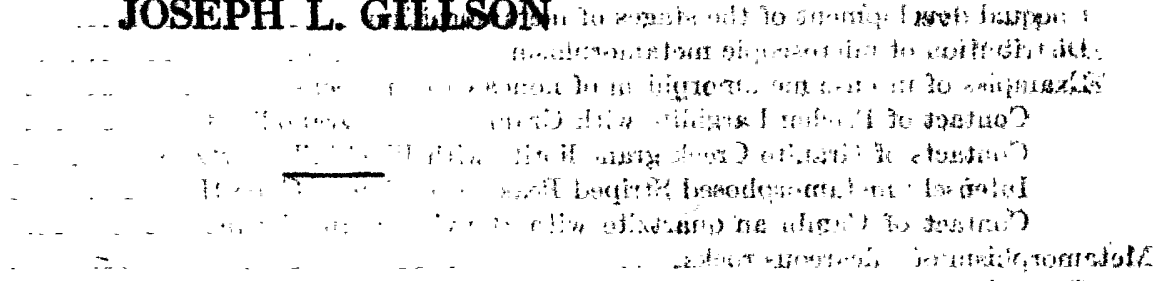

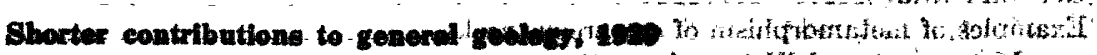
(Pasei 111-121)

A I: I:

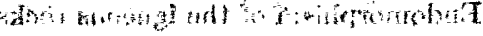

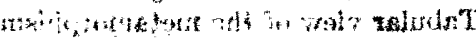

;

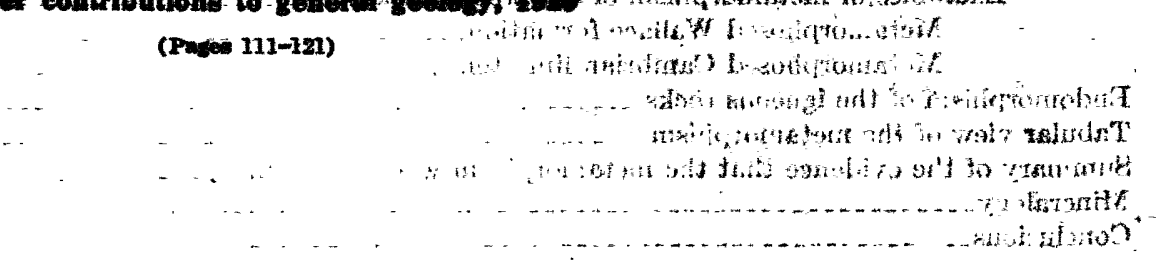

UNTTED STATRS

COVRRAMENT PRINTING OPJCE

WASHINGTON : 1929

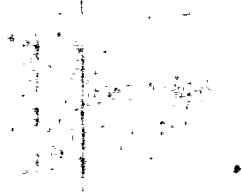

or sale by the Superintendent of Documents, Washington, D. C. 


\section{CONTENTS}

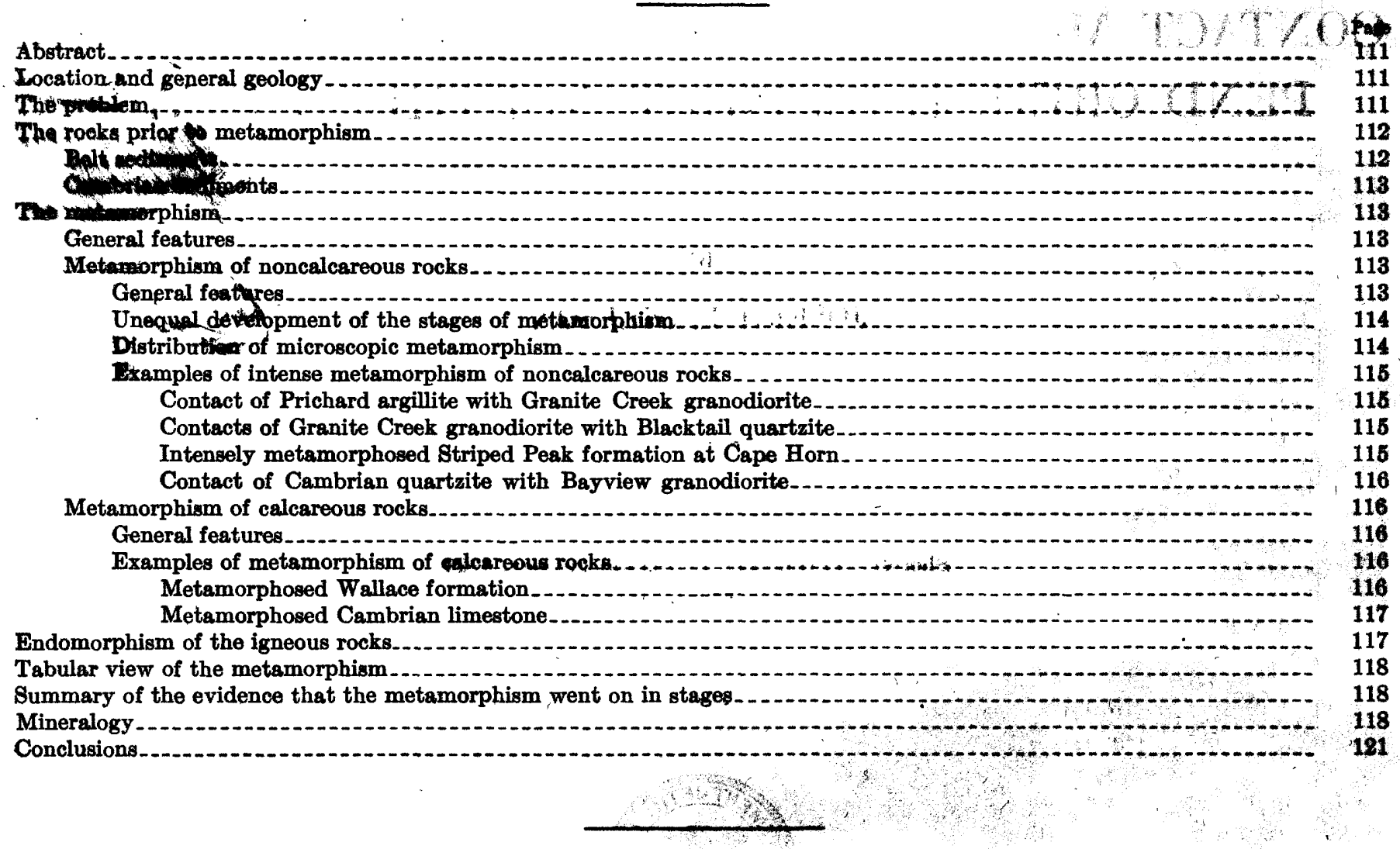

\section{ILLUSTRATIONS}

Puam 15. A block of the Wallace formation found on the beach of Pend Oreille Lake near Talaghe, Idaho.

Fraurn 16. Map of the Pend Oreille area, Bonner County, Idaho . 17. Sketch from photographs taken from hill north of Lakeview, Idaho 


\title{
GONTACT METAMORPHISM OF THE ROCKS IN THE PEND OREILLE DISTRIC NORTHERN IDAHO
}

\author{
By Josurat L. Grimor.
}

\begin{abstract}
Amsract
In the Pend Oreille district, Idaho, a section of sedimentw, part belonging to the Belt ceries, of Algonkian age, and part to the Cambrian system, was intruded and intensely metamorphosed by granodionites of late Mesozoic or early Tertiary afe. This metamorphiam proceeded in three overlapping stages. During the intrusion of the igneous roeks a general recryatallization of the sediments took plice, the siliceenus rooks changing to adinoles near the contacts and to platioclase-bearing rocks at greater distances and the limestones turning to marbles. Later, during the eryatallization of the granodiorftes, emanations carrying the so-called mineralisers were given off in quiantity and formed high-temperature silicates in the sediments. Still Iater, fter the igheous rocks had solldified and the temperature of the masses had become lower, sericite, chlorite, serpentine, magnetite, and sulphides were formed by replacement of the earter minertli. Although no tuibe mathials were found in the oontact zones, inore than

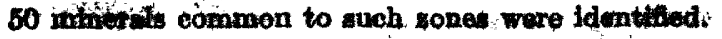

\section{LOCATION AND GENERAL GBOLOGY}

The Pend Oreille silver-mining district lies in Bonner County, in the panhandle of Idaho, and is adjacent to the south arm of Pend Oreille Lake, a large body of water lying in a tremendous glacier-cut trough. (See fig. 16.) An area about 15 miles wide and 20 miles long was studied by a party of the United States Geological Survey under Edward Sampson in the summers of 1921, 1922, and 1924, and in the support of this study the Idaho State Bureau of Mines and Geology kindly cooperated. ${ }^{1}$

The district is underlain by sediments of Algonkian age (the Belt series) and Cambrian age intruded by igneous rocks, the largest masses of which, at least, are of late Mesozoic or early Tertiary age. These igneous rocks, which crop out over about one-fifth of the land area, have already been described by the writer. ${ }^{2}$

The surface character of a part of the district and some of the geologic features are shown in Figure 17.

1 Sampeon, Edwerd, Gealogy and stretore depoits of the Pend Oxthe dib trict, Idaho: Idsho Bur. Mines and Coolocs Pamph. 31, 1928.

aillson, J. L., Granodiorites in the Pend Oreifle district of notthern Ideho: Jour. Gealogy, vol, at, pp. 1-81, 1987. $48802^{\circ}-20$

\section{ThITROALEM}

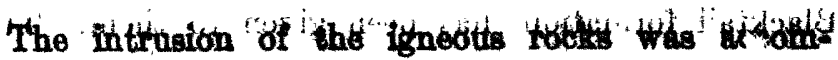
panied by metamarphiam so intense that in few $f^{\text {lnceg }}$ are the sediments free from its effects. The stuty of the rocks of the district has shown that the ymoend of ignoous mistamoiphism long contionde and

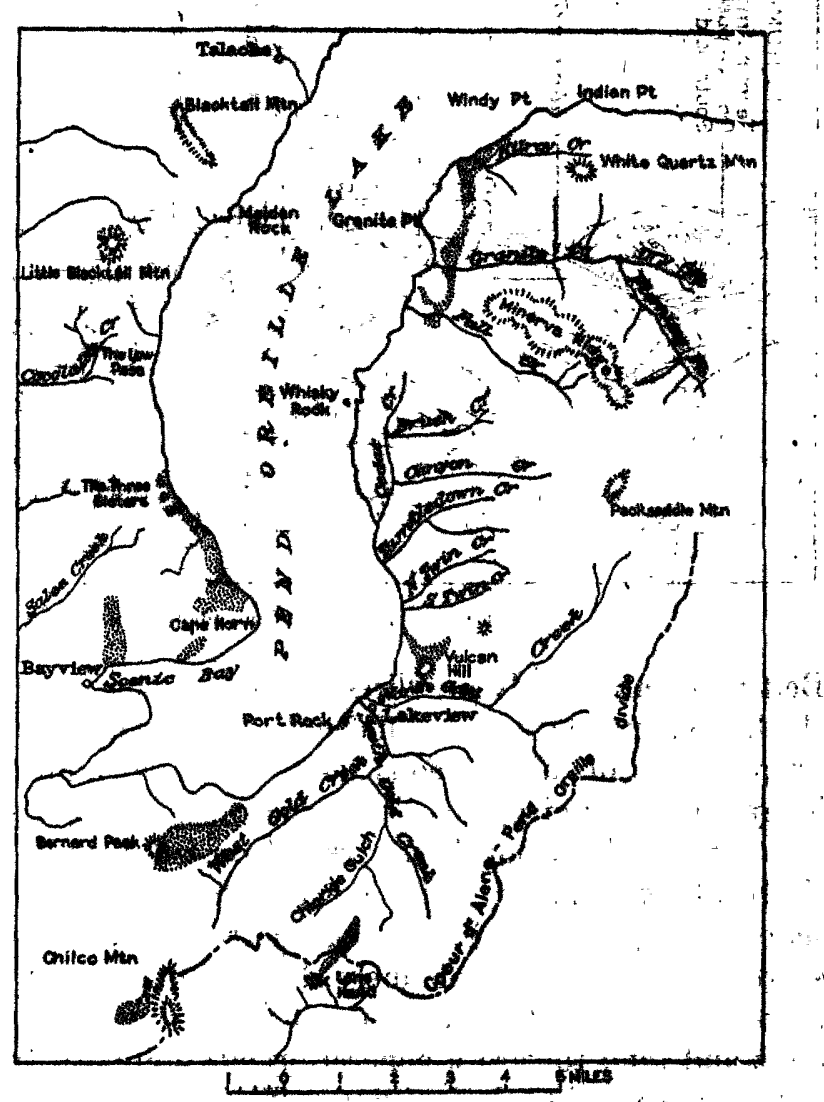

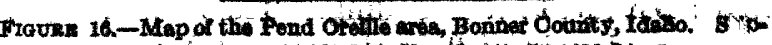

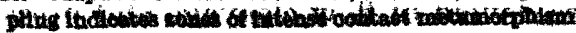

that conditions progreasizely changed during the crystallization of the magma. Three periods or tagee in the metemorphism can be reoognimed/ and the chisf purposes of this paper ere taprope thet then ftagen ocourred and to deearibe them. The calonpous rocks were changed in a different manner from the mon- 
calcareous rocks, and the difference indicates that the primary character of the sediments was an important factor in the metamorphism. Furthermore, considerable material was introduced during all three stages of the metamorphism.

\section{THE ROCKS PRIOR TO METAMORPHISM}

The section of Belt rocks in the Pend Oreille distriot is similar to that in the near-by Coeur d'Alene district, described by Ransome and Calkins. ${ }^{3}$ The Pend Oreille section differs principally from that in the Coeur d'Alene district in that the rocks at the horizons of the Revett and St. Regis formations-that is, the rocks underlying the Wallace formation and overlying the Burke formation-are toore silicootis, and a new name, Blacktail formation, has been given to them. The to be of algal origin. The Striped Peak, the uppermost formation of the series, is also locally calcar ous.

Belt sediments.-The beds of the lowest formation, the Prichard, consist of dark-colored aryillite and grayish quartzite. Some beds of the quartzite are fairly coarse grained. Many of the beds are closely laminated, owing to frequent alternations of sand and

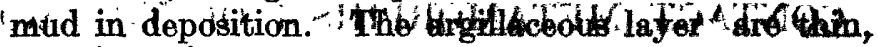
black, and in many places very closely spacad.

The Burke formation, which overlies the Prichard, consists of thin layers of medium-gray fine-grained light-weathering quartzite interbedded with dark-gray siliceous argillite, the bedding surfaces of which are micaceous, are either green or nearly l'ack, and exhibit conspicuous mud cracles. Some of the quartzite has a distinctly bluish tint on fresh fracture. Some

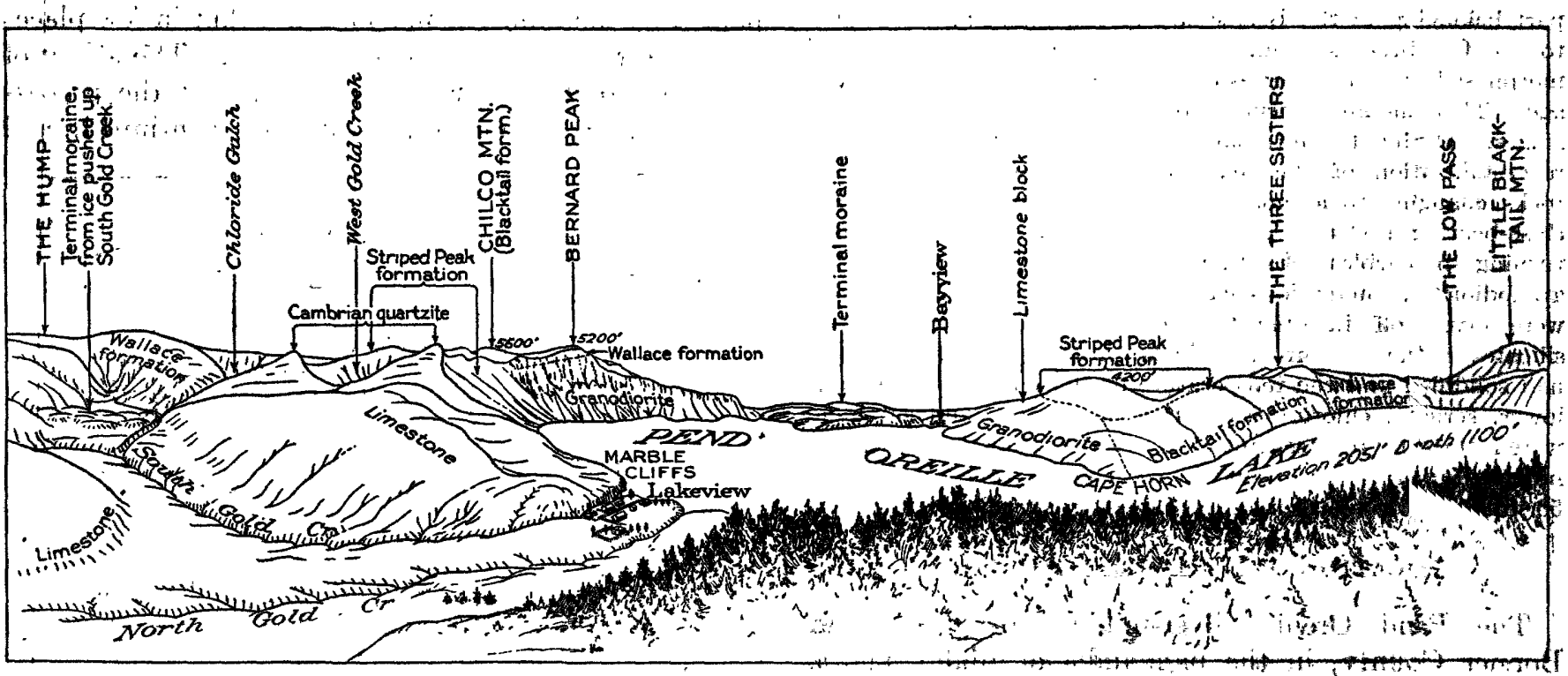

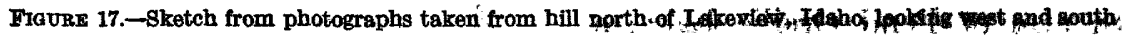

काष

Belt rocks are chiefly argillites and quartzites of great thickness, and the strata differ only in color and in the proportions of argillaceous and siliceous material. They are affected by load metamorphism, and where not contact-metamorphosed they consist almost entirely of quartz and white mica. Under the microscope the quartz grains appear detrital and each is surrounded by a film of finely divided mica. In the more argillaceous beds the mica flakes are very abundant and tend toward a general orientation with their flat sides parallel to the bedding. The rocks are almost everywhere devoid of flow cleavage and preserve such sedimentary features as ripple marks, cross-bedding, mud cracks, clay galls, and rarely casts of salt erystals. The Wallace formation, which overlies the Blacktail, differs from the rest of the series in that it containg almost throughout a considerable amount of calcite, which is present in very peculiar structures, considered

Ransome, F. L., and Calkins, F. C., Geology and ore deposits of the Coeur d'Alene district, Idaho: U. S. Geol. Survey Prof. Paper 62, pp. 29-44, 1908. beds are laninated others aro not. Somo thick masses: of hepy

The lower part of the Blacktail format wh, which overlies the Burke, is dominantity a ver massive bluish-gray quartzite that weathers nearly black qud breaks into large rectangular blocks $q$ exposed faces across the bedding discontinuous graysh or purplish bands occur, abundant in some be s, $^{2}$ rare or absent in others. The bedding surfaces are thit shaly partings pirple of maroon, lustrous and conspicuously mud cracked and ipple marked. "The upper part of the formation "s more argilla eous, and the purple shaly partings are closely spaced. Many layers of the upper part are green but do not differ otherwise from the fest

The lithology of the succeeding Wallace formation is varied, but two features appear in so many of the beds that its identification was usually simple.' The argillaceous partings of thin-bedded quartaite expose: a bedding surface of lustrous black, on which are con- 


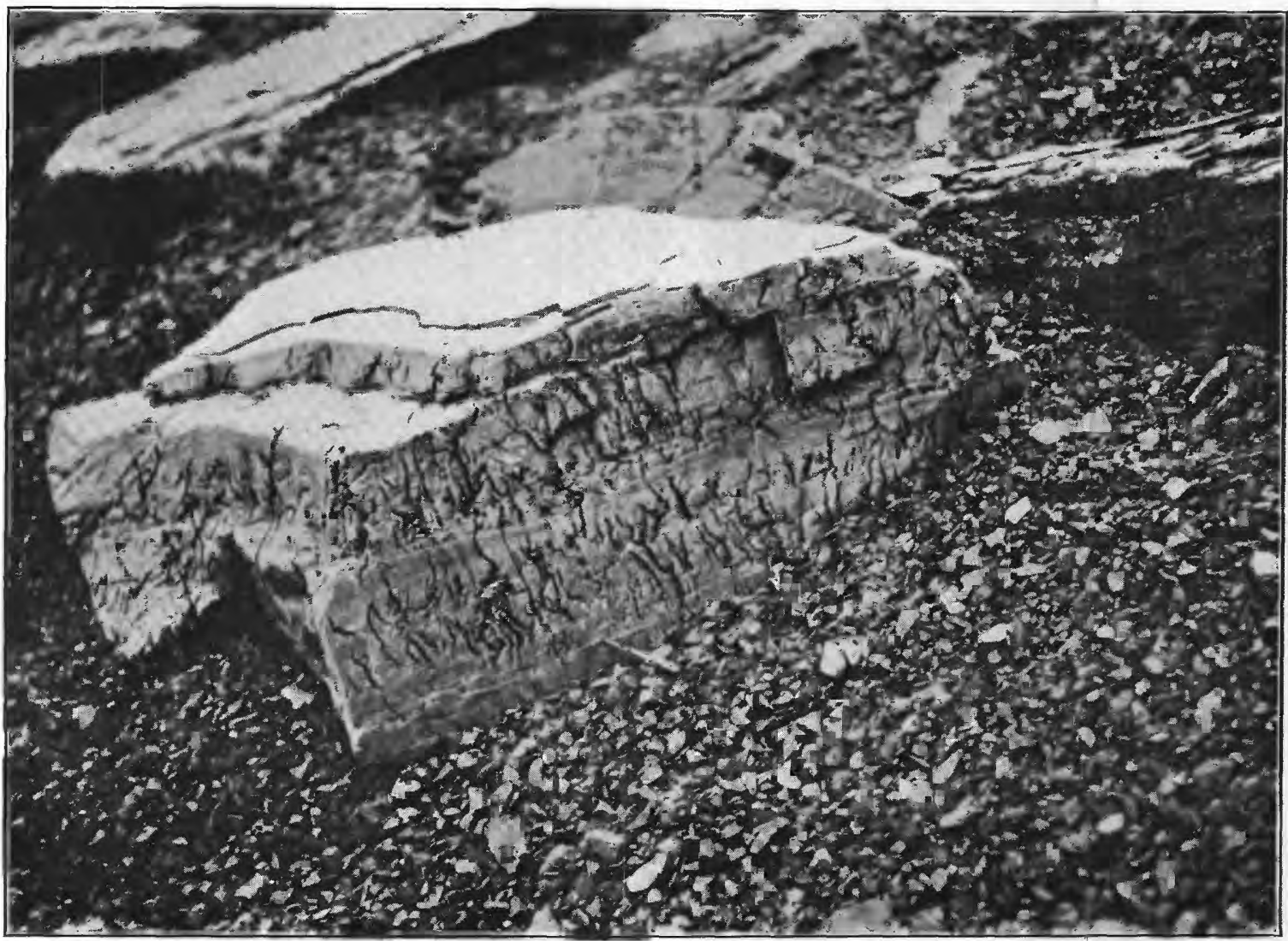

A BLOCK OF THE WALLACE FORMATION, 10 BY 18 BY 24 INCHES IN SIZE, FOUND ON THE BEACH OF PEND OREILLE LAKE NEAR TALACHE, IDAHO Shows the peculiar contorted cavities caused by the more rapid solution of the calcite bodies than of the rest of the rock. These
cavities are believed to be of algal origin. 
spicuous mud cracks. Also, the peculiar struetures of calcite above mentioned are especially diagnostic. The calcite masses are fine grained, and most of them are elongated in two directions at right angles. The vertical cross section is the most striking. It shows a peculiar wavy band from 0.5 to 4 millimeters wide and from 0.5 to 6 centimeters high. Some cross sections resemble: a question mark, into which a fow extra crooks have been put. Owing to the more rapid solution of the calcite these structures are represented on weathered surfaces by cavities, and by them the formation was generally distinguished. (See pl. 15.) These calcite masses modified the metamorphism to a different type from that prevailing in the surrounding noncalcareous materials, and in intensely metamorphosed beds they were seen as pseudomorphs. Argillaceous beds of the Wallace are black on fresh fracture but weather buff. A flinty green argillite is found at the bottom of the formation, and at the top the beds are closely laminated, similarly to those in the Striped Peak formation.

The Striped Peak, the top formation in the Belt series in the Pend Oreille district, is a thin-bedded fissile dark-gray argillite with interbedded white quartzite. Brick-red is the predominant color on exposed surfaces. Mud cracks and ripple marks, fow of which are more than a centimeter in width, are conspicuous on the beds. The intercalation of many thin argillite and quartzite layers, 15 or 20 to the inch, is a characteristic feature of the formation. A considerable thickness of the Striped Peak differs, however, from the main type and is an unlaminated olive-drab graywacke. At least at one horizon the upper part of the formation contains irregular masses of calcite similar to those in the Wallace.

Cambrian sediments.-The Cambrian rocks comprise a massive conglomeratic quartzite, a thin-bedded friable shale, locally fossiliferous, and a thick limestone with several facies, fossiliferous at same horizons. The quartzite probably corresponds to the Flathead quartzite of Montana; the shale contains a small fauna of Middle Cambrian age. The fossils of one stratum of the limestone correspond with those of the Langston limestone of the Blacksmith Fork section in Utah, and a shale in the limestone may be correlated with the Spence shale member of the Ute limestane of Utah."

\section{THE METAMORPHISM}

GENERAL FEATURES

Each sedimentary formation was found to be profoundly metamorphosed somewhere in the district, and each was nearly everywhere slightly metamorphosed. The zones of intense metamorphism, in which complete recrystallization had taken place with an almost total elimination of sedimentary characters,

4.Walcott, C. D., Smithsonian Misc. Coll., vol. 53, pp. 191, 197, 1908. are relatively; amall, fow ibaing more than 200 /y and

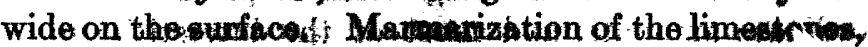
however, was'thore widespnead; and at somer pltines

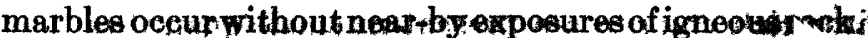

The metamorphism of the Prichard, the Burdenthe Blacktail, the noncalcareous part of the Striped F-ak, and the Cambrian quartzito is 'so similar as to 946 thire no separate description. The metamorphosed ealcareous rocks contain many fostures in opmonn, although the Wallace and the calcareous pato of the Striped Peak, being dominantly argillaceous, iffon from the metamorphic poduct of the purer Camb inp limestone.

"*ffrity

The igneous rocks that enused the exomorphign" of the sediments are in no place sevaraly endopopphs sed. In a narrow zone, close to the walla the intrusiyegr ${ }^{\prime}$ nodiorite contains muscovite and has been rather intensely affected by sericitimation and chloritization accompanied by the formation of eonsiderable magnetite. Locally molybdenite and other sulphides formed in the endomorphic zone.

\section{METAMORPEIST OF TOHCATCABHOOS ROCER}

\section{GHNDRAI THATURES}

The more intense metamorphism of the nor ralcareous rocks has visibly changed them. They are commonly spotted, and crystals of biotite and mu neovite a millimeter in dismeter can be distinguis The more argillaceous beds have become more resistant to erosion and make bold outerops. The mictosrope shows that the old fabric of texture and structure has been very largely preserved, but the quartz and fi divided white mica have been replaced by oligoclasealbite with or without quartz. The feldspar cryi fils are of the same size as the former quartz grains and make a mosaic of interlocking anhedral gritis. Irregularly distributed in this fabric are crystal of biotite, andalusite, tourmaline, apatite, zircon, and iron-rich chlorite and muscovite, most of which ar of anhedral form and in general much larger than the quartz and feldspar. All were formed whthout recard to the boundaries of the feldspar and quartz and are clearly replacements of those minerals. "Lates finely divided sericite and chlorite were deposited by réplacement of all these other minerals, and last of all magnetite, pyrite, and pyrrhotite wore formed it the soricite and chlorite.

There were thus three rather well-defineal period's of mineral formation-first a period of recrystallization and substitution of a sodic plagioclase for the rica and some of the quartz, later a period of fornitition of high-temperature silicates, "and finally a perioce of sericitization with the formation of magnetite and sulphides.

Farther from the contact the changes that vent on in the rocks differ only in degree from those just. 
described. The sodic plagioclase is present in subordinate amounts, and most of the interstitial mica of the load metamorphism remains. The biotite and iron-rich chlorite are present in emall quantities, but magnetite and sulphides are more rare.

UNDQUAL DEVELOPMENT OF THE STAGIS OF METAMORPHISM

The moderately metamorphosed rocks were not in general affected equally by the three stages of metamorphism. For example, a bed of white quartzite in the Wallace formation exposed on the shoulder of the spur on the north side of Dry Fork, near the mouth of Fleming Fork, was entirely recrystallized to an allotriomorphic aggregate of quartz and albite-oligoclase, the average grain size of which is about 0.05 millimeter. A few minute tourmaline prisms are seen in thin section, but there is no biotite, chlorite, sericite, or magnetite. Thus the rock was strongly affected by the first stage of metamorphism but hardly at all by the later stages.

Many other examples of this unequal development of the metamorphism could be given. The beds in Maiden Rock belong to the Blacktail formation and were recrystallized during the first stage, with the formation of much feldspar, but only a few rhombs of a late carbonate resulted at a later stage. The Blacktail beds at the summit of Chilco Mountain were not at all affected by the first stage, but biotite and tourmaline are abundant in them as replacement minerals. The Burke quartzite in the tunnel of the Phil Sheridan mine, on the north side of Granite Creek near its mouth, and in contact with the Granite Creek granodiorite at the lake shore, a short distance north of the mouth of the creek, was intensively metamorphosed only during the third stage of metamorphism. It contains pea-sized aggregates of late sericite, with chlorite, magnetite, pyrite, pyrrhotite, and some calcite. Only a little feldspar, biotite, apatite, and zircon were formed in earlier stages. At a point on the west side of the Chilco Mountain ridge the Blacktail quartzite was found to have been intensively metamorphosed during the third stage, so that the oarlier metamorphic minerals, once rather abundant, were almost completely eliminated. This lack of relation of the stages of metamorphism affords one of the best proofs that the metamorphism took place in stages.

\section{DISTRIBUTION OF MICROSCOPIC METAMORPHISM}

Examples of beds that had not been metamorphosed were sought with care, in order to compare the entirely. unmetamorphosed phases of each formation with the metamorphosed phases. During the early part of the field work it was not realized how widespread the metamorphism is, for except near the contacts of the igneous rocks the sediments are not visibly contact metamorphodi Then thin sections of raks supposed to be unmetemorphosed were oxamine $d$, it was

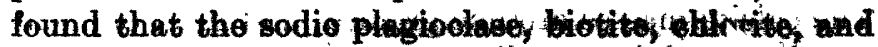

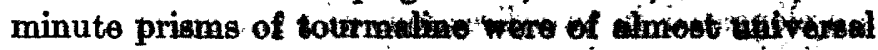
occurrence. Study showred, hower, that th ntwinin-

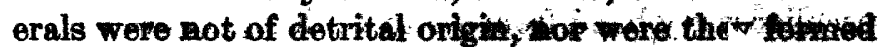

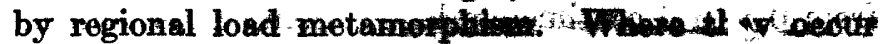

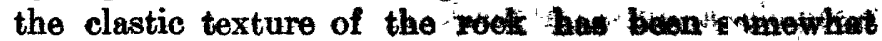
obliterated, whereas in the rocke of the monthol clastic character these minerals are about. Detrital feldspar occurs in some beds, but the grain are rounded by a film of serieitio material. The sodie plagioclase occurs as fresh glassy erystals that interloek with one another or with the quartz. Foils $c^{f}$ detrital biotite were found interstitially between elastie quartz grains; the metamorphic biotite has replnced the quartz grains, and a great many are larger than the average grain size of the rock. The tourmali v prisms have likewise replaced adjacent quartz grains. The tourmaline is remarkably widespread, being $\Gamma^{\text {resent }}$ at almost every point where specimens were collected. Calkins ${ }^{5}$ found this universal distribution in the roeks of the Coeur d'Alene district, and he alse ornisidered it to be of metasomatic origin. Tourmaline was not found in rocks showing no other effects of metamorphism but was invariably accompanied by feldspar and biotite.

Proof that these minerals were not formed by recrystallization in the course of the load metamonphism that turned the old sediments into argillites and quartzites is afforded by the fact the sueh sericitic quartzites or siliceous argillites were thow by analysis to be low in soda, iron, and magnesia. Furthermore, so ubiquitous a distributien ${ }^{r}$ of tourmaline, if it was formed by recrystallizati of an earlier detrital generation of tourmatine, den'ands the ultimate source to have been a metamorphin terrane; from which other motation hic minerals shenld have been earried in with the teumaline. No suct mindrals have been folund as detrital or rerystillited griting in the roeks of the Belt meries. The tourma "no must therefore indicate that fineous rolntions have pased through these foeliks.

Additional prod that the tourmatime; biotite, foldspar, etc., were formed by the aetion of solutions. migrating trom the intrusive granodionte ir afforded by the increasing abundapce of tha identical varieties of these minerals found in the sume beds to vard the igneous contacts.

Another minoral, rathe widesper in the Belt rocks and alsa belipred to have beep formed by alus tions from the trnoou waune, carbcrate. A variely of ankerite wa fand to be the mat abundant species, and the rhombic form the most eharateristion of the eccurrences. The oarbonate was found in evers

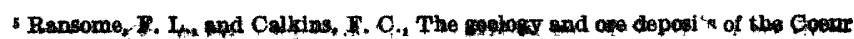

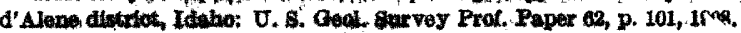


Belt formation except the Butre find is thost ubundant in the Walluce and in the Cumbrian limestene. Because of the greater abundane in originally caleareous rocks it is probable that most of the carbon dioxide was derived from the sediment ftself. As there was no apparent change in valume, some introduction of $\mathrm{CO}_{2}, \mathrm{Fe}$, and $\mathrm{Mg}$ must be supposed to make ankerite from caleite.

MXAMPLES OF INTENST MITAMORPHIM OF NONCALCAREOUS ROCKS

Contact of Prichard angillite with Granite Creek gnanadiorite.-The igneous oantact is sharply exposed on the east shore of the lake north of Granite Point. The well-defined bedding of the sedimentery rock is obliterated for approximately 100 feet, and the hornfels is cut by meny quertz veins. For 25 feet from the contact the rock is a dense aggregate of quartz and albite but contrins also biotite, zircon, apatite, and ilmenite. The albite decreases in abundance away from the contact.

Chemical analyses of the adinole at the contact and of a semple of the argillite collected at some distance from it definitely prove that an increase in soda and a loss in potash took place during motamorphism. There was also an tunmistakable increase in iron, phosphorus, and zirconis and probably. in lime, magnesia, and titanium.

Analyses of metamorphosed Prichard arghtite [J. G. Fairohild, Analyst]

\begin{tabular}{|c|c|c|}
\hline & $\begin{array}{c}\text { Contact } \\
\text { roek }\end{array}$ & $\begin{array}{l}\text { slightly } \\
\text { metamor- } \\
\text { phosed } \\
\text { rock a }\end{array}$ \\
\hline \multirow[t]{2}{*}{ 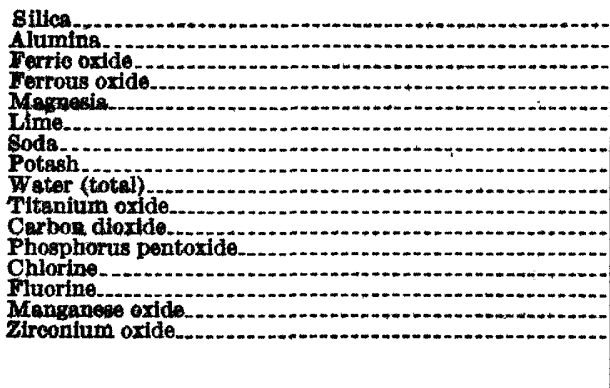 } & $\begin{array}{r}66.96 \\
15.42 \\
4.68 \\
4.19 \\
2.01 \\
.62 \\
6.57 \\
\text { Trace. } \\
1.96 \\
1.00 \\
\text { Nane. } \\
\text { None. } \\
\text { None. } \\
\text { None. } \\
.06 \\
.07 \\
\end{array}$ & $\begin{array}{r}69.06 \\
15.91 \\
1.21 \\
3.17 \\
1.00 \\
\text { None. } \\
1.62 \\
3.96 \\
1.98 \\
\text { None. } \\
\text { None. } \\
\text { Trace. } \\
\text { None. } \\
\text { None. } \\
\text { Treace. } \\
\text { b.03. }\end{array}$ \\
\hline & 99.77 & 78 \\
\hline
\end{tabular}

Contains arganic carbon, probabiy graphitic
Accuracy of the ziroonium deternination sald by Mr. Fairchtld to be 0.005 .

Contacts of Granite Creek granadionite with Blacktaid quartzite.-A contact of Blacktail quartzite with the Granite Creek granodiorite is well exposed on the east side of the lake near the mouth of Fall Creek. The sediment near the contact is spotted with black knots of biotite 1 to 2 millimeters in diameter or is streaked and mottled with biotite and muscovite aggregates. The igneous rock contains visible crystals of muscovite and is seen under the microscope to have been also sericitized and enriched in magnetite.

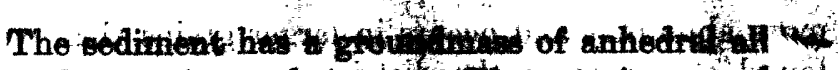

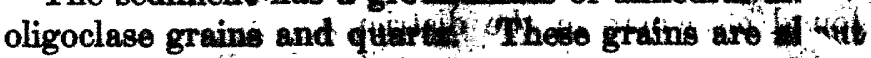

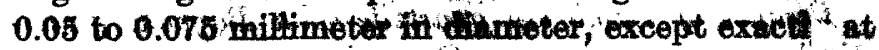
the contivet, where they he twice this size. "neth placing this groundindos larger quartz graila otud abundant irregularly thaped grains of biotite, thitsot vite, and endalusite, many $0 t$ which are gevertat as large as those of the gitomdnass. Mueh bitho andaluaite is partly slfored to tifinely divided thet in

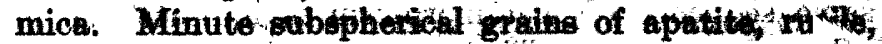

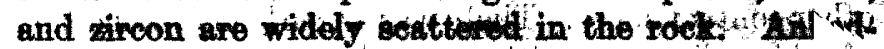
rons of magnetite and ilmenito, about $0.05 \mathrm{~m}$ mintint in diameter and diesemitiatiod in the most reminth manner, wore certainly the latest mineruls to forts

On the west slope of Chilco Mountain the wie formation is in contact with Bayriew batho it th? but exposures are poor. The roek was recryotall ind to an aggregate of quartz; microcline, and stubondicate oligoclase-albite, with Hittle therense in size of gintit. Later larger erystals of mulucovite, quartz, biotite, thit andalusite formed, many of the grains of which of more than a millimeter tin diameter. Minite exyt iall of zircon and blebs of ext unidentified mineral hating about the refractive indice and birefringence of pyroxene are abundant. Many of the undattefted grains are poikilitic, resembling a graphite interget with quartz. . In the latar stage of the metemorpl iam the biotite was altered to chlorite with the separation of rutile needles, making sagenitic structures; the andalusite and feldeper were stricitizad. In wany of the large crystale of muscovit very peen liar spherulites of serieite formed, the individual new llas of which are hairlike, and many ax as long as an millimeter.

Intensely metamorphosed Striped Peal formation at Cape Horn.-Metamarphoned beds of the 8twined Peak formation ocear 1,700 to 2,000 feot above the lake on the south aide of Cape Hom. The charaoteristic banding of the formation (as in sectina) is preserved, and the rock aplite faiply. Well along the bedding. The dark bande ere rusky brown; the l tht ones yellow-brown. Some of the light bends atro marked with dark spots. The microscope shown that the three stages of motemorphim are well indicated. The groundmass consists of intenlocking grain of quartz, microoline, and, albito-aligoelase, in which

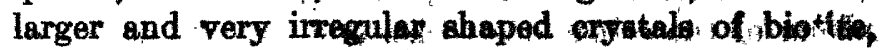
muscovite, and tourmaline had developed at 1 ktar time. Small crystale of aircon end apetito sory constituents of the second etege of metarionphism. Magnatite, rericite, and ohlorite farmed leter, as is indicated by the oross outting of the grains and the replecement by them of biotite and folderan. The amount of feldepear that had formed during the early period was ralatively. less then in other similudy severely metamorphos rocks. The tourmalina is 
more abundant and occurs in larger grains than were found elsewhere in the district.

Contact of Cambrian quartzite with Bayview granofiorite.-A contact of the Cambrian quartzite with the granodionite is exposed in the field east of the summer residence known as Dromore, northeast of Bayview. The sediment at the contact is a gray rock flecked with minute biotite scales and having an average grain size of 0.5 millimeter. In places it is faintly banded. The same sequence of metamorphism is indicated as in other contact zones. There was an early crystallization of albite-oligoclase with the quartz, forming an interlocking groundmass, the grains of which average about 0.1 millimeter in diameter. The feldspar is not uniformly distributed, making solid masses in some parts of the thin sections, and being absent from other parts. Biotite, muscovite, andalusite, and tourmaline formed abundantly; the tourmaline is found in small grains, the others in large ones. Many of the biotite foils contain zircon crystals surrounded by pleochroic halos, and many foils are also altered to thuringite, with the separation of rutile needles. Sericitization had been intense and widespread, attacking most successfully the feldspar and andalusite. Magnetite and ilmenite are also abundant; many of the grains of the ilmenite are partly altered to leucoxene.

\section{METAMORPHISM OF CALCAREOUS ROCKS}

\section{GENERAL FEATURES}

The mineralogy of the metamorphosed Wallace formation and of the Cambrian limestone is so strikingly different from that of the rocks above described that it indicates the inportance of the original character of the rock in determining the nature of the minerals formed by metamorphism. Albite, andalusite, a biotite with very high index of refraction, tourmaline, and thuringite are characteristic of the metamorphism of the noncalcareous sediments, but in those in which calcite was originally present garnet, diopside, a magnesian biotite, amphibole, epidote, and titanite are abundantly developed, and scapolite, vesuvianite, olivine, chondrodite, topaz, and fluorite were found in a few places. On the other hand, zircon, quartz, apatite, sericite, chlorite, magnetite, and sulphides occur in both kinds of rock.

There were two distinct processes in the metamorphism of the calcareous rocks, and like the stages of metamorphism in the noncalcareous sediments the degree of development of one is more or less independent of the other. There was first marmarization of the limestones on a large scale, which eliminated the bedding and the carbonaceous material. Later came the introduction of material from the igneous rock, which formed the contact silicates above mentioned. This second process is conveniently divided into two stages on a rough basis of temperature, with sericite and ohlorite marking the beginning of the later stage. There were thus thre etages o lso in the metamorphism of the calcareous moaks

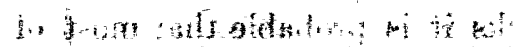

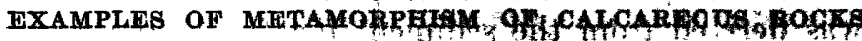

Metamorphosed Wallace yombition The theldong

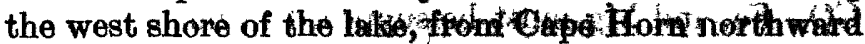
under the Three Sisters, is all metamorph bed, but through much of this distance the exposures congist of the Blacktail formation. Farther north are found greenish and white quartzite beds, characteristio of the metamorphosed Wallace, the identity o whel is established by the presence of the typical tretwork shown in section, which prior to metamorishism contsisted of calcite structures" of organic orimin." The grains are very small, and the rock has a subronchoidal fracture. The green bands consist of a pale-green amphibole; the white bands are either of quartand feldspar, quartz and scapolite, or diopside, which in some beds makes nearly solid masses. Zoüsi $e$, bietite, grossularite, titanite, zircon, apatite, and muscovite are accessory minerals.

The climb up the east side of Bernard Thak from West Gold Creek, at the south end of the lake, gives another instructive section of metamorphose $\mathrm{A}$ Wallace beds, there present as a capping over the Bayview granodiorite, which is exposed almost to the top of the tremendous cliff that rises abruptly from the shore. The same rock is also seen in the gap between Bernard Peak and Chilco Mountain. This rock is massive, is marked with white or white and green bands, and is notably heavy from the abundance of heav silicates. The grain, however, is so fine that no minerals can be recognized with the hand lens. The mineral content is about the same as that of the roek along the chore under the Three Sisters, consisting of quart - fotdspar (both microcline and albite), diopside, zoisite, garniet; titanite, zircon, apatite, calcite, and magnetite. The pyroxene and amphiboles are distinetly later than the feldspar. Titsinite is very abundant in soms beds bat ocours in minut grains. A pale-brown biotite ndos up 30 per cent of eeme beds but is entiryly atosent from others.

Another are of intenisely motamorphosed rocks is on the slope enst of thithewer wine, near, the divide separating Chloride Gulch from the tributa ries of the North Fork of Coour d'Alene River, at the south edge of the district: No igriobus rocks are exjosed; but minute seams of pegmatite were found contaithing quartz, potash, feldspur, eptdote, and mogtotite. Beds at an altitude of 3,750 fet ditedty obove the Hewer mine were "stuatiat 1 he rock at a dense greenish hornfels, consisting of a groundmas" of quarti and microcline, in which are numerous finely divided prisms of the green ainphibole, accompanief in some beds by a fibrous amphifbole of lower refractive index. 
Zircon, tithithite, apatite, and magnetite tare soattered widely through the rock.

In the metamorphic area just described but beyond the divide, in the North Fork drainage basin near the Lone Hand prospect, the difference between the minerals formed during metamorphism of calcareous and noncalcareous beds is convincingly demonstrated. In some laminae within a single thin section are quartz, sodic plagioclase, and andalusite, with sericite and chlorite-the typical mineralization of the siliceous sediment; whereas in adjacent originally calcareous laminae are epidote, diopside, amphibole, fluorite, titamite, and calcite. In some places the calcite forms pseudiomorphs after the amphibole. During a mechanieal "separation of one unbanded specimen in brotnoform, three-fourths of the powder sank, and of this fraction 95 per cent was amphibole.

Hatamorphosed Cambrian timestone.-The Cambrian limestone is marmarized, or partly so, over large areas. At the lime quarries near Bayview, at the old quaries at the head of Cocolalla Creek and near Whiskey Rock, and in the headwaters of North Gold Creek the rock is marmarized but contains few silicater The most interesting examples of more intense metamorphism were found in an included block of limestone on the south side of Cape Horn, in cliff's along the east shore between South Gold Creek and Port, Rock, and at Vulcan Hill, east of Lakeview. These zones have a varied mineralogy and present the most interest to the mineralogist of all the contact zones in the district.

11 Anumber of prospects for ore on Vulcan Hill have made|good exposures of the contact of the granodiorite and limestone. The sediment is a white marble in which many silicates and some ore minerals were lodblly developed so abundantly that the rock is entirely replaced by them. In some beds the rock is banded green and yellow and consists principally of garnet and augite but also contains vesuvianite, epidote, phologopite, amphibole, fluorite, quartz, serfitite, chlorite, zeolites, magnetite, sulphides, and ankerite. In some closely banded shaly limestones the effect of alternating composition is again clearly demonstrated. Sodic plagioclase formed in the shaly layers, but at that stage of mineralization no silicate formed in the limestone beds, and the rock only recrystallized to marble. Later biotite formed in the shale, and garriet, diopside, and amphibole formed in the limestope. The later sericite and chlorite formed in both without regard to the boundaries of the layers. In one bed a considerable quantity of corundim was fouthd, apparently produced from the recrystallization of an impure bed in the limestone.

The garnet and pyroxene differ in composition in adjacent beds of the limestone and indeed in the same bed, as the garnets are zoned in some places. The difference in zoned garnets, however, is slight, but in

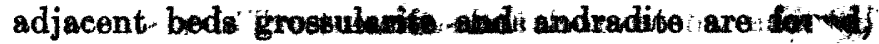
and diopside and augitds ceour at different hotiman

In the garnet zone lon Gape: Hoin a fewriver minerals occur in subordinate quantity, topax, bytownite, and allanite being identified microseopiorly. Some marble cliffs on the east shore of the atre, between the mouth of South Gold Creek and Ret R nk, also yielded additional minerals. At the east ond of a little beich 100 yards south of the mouth of the creek the rock is a light-gray and green', partly rec'ystallized but still bedded limestone. Besides ankerite, scapolite, spinel, muscovito, and ehlorito, considerr ble chondrodite is present in small palo-yellow crystals, a few of which can be seen with a handlens. Farther. southwest, beyond a fault, the rock is more thoroughly marmarized and contains diopside, phlogopite, and tremolite and in the more shaty layers sodic plagioclase and quartz.

The independence, of marmarization and silicate formation was well shown at the last saries of outerops. Marble occurs without-silieates, and silicate found in bedded limestone that is but little marmarirgd. Where silicates occur in marble the indieate by their boundary relations, so far as these can be interpreted; that they. were formed later than the marmarization. From these facts it is inferred that marmarization took place principally during the first effusion of solutions from the magma, mostly of water, wh mixed with and hated water of connate or of surface origin, whereas the silicates formed later, after the advance of crystallization in the igneous rocks had caused a concentration of the emanations by adding more material in solution.

\section{ENDOMORPWISM OR TWD IGNIOES AOCK}

The writer has elsewhere briefly described the endomorphism of the igneous rocks and has connected it, at least in a general way, with the action of the ss rae solutions that slowly soaked through the body of the igneous rock and made a number of postconsolidat changes. At fow points are the rocks conspicuor ily endomorphosed, and except for some changes visible onty under the microscope the rocks appear the sene at the sedimentary contracts as elsewere. The ac $\mathrm{d}$ tion of large flakes of muscotite, in intense sericitization and chloritization, and the enrichment of magnetite were the endomorphic chainges. The muscovite is not pyrogenetic, for it has replaced éarlier miner /s. If its time of formation in the igneouls rocks can be fixed as contemporaneous with that in the adjacint sediments, the time of their metamorphism in relat in to the crystallization of the igneous rock is relatively well established. It seems to the writer that the time of crystallization of the muscovite must have ben contemporaneous on the two sides of a sharp contact

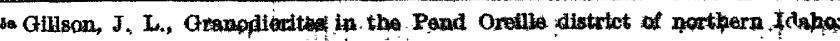
Jour. Geology, vol, 35, p. 20, 1927. 
between igneous rock and sediment. This essumption furnisher a basis for the dating of the stages of metamorphism in the sediments.
TABULAR VIEW OF THE METAMOAM

The metamorphism of the reeks in thig I and Qpeille area can be whown in tebular fosin as folliow:

Metamarphism of rocks in Pend Oreille district, Idaho

\begin{tabular}{|c|c|c|c|}
\hline Stage & Igneous rook & Noncalcareous sediments & . \\
\hline 1 & Magma molten........ & $\begin{array}{l}\text { A general and uniform recrystallization, } \\
\text { with obliteration of the undulatory ex- } \\
\text { tinotion of the quartz, elimination of the } \\
\text { sericite, and the formation of more or less } \\
\text { feldspar. }\end{array}$ & 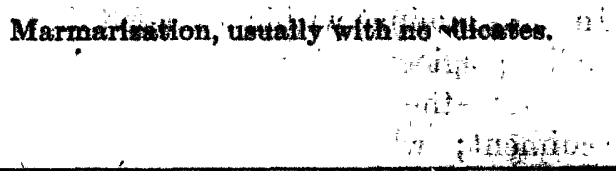 \\
\hline 2 & $\begin{array}{l}\text { Magma orystallising and mar- } \\
\text { gin probably aolid. }\end{array}$ & $\begin{array}{l}\text { Pneumatolytic emanations carrying the ele- } \\
\text { ments known as mineralizers. The min- } \\
\text { erals that formed are andalusite, biotite, } \\
\text { cordierite, tourmaline, quartz, apatite, } \\
\text { and sircon. }\end{array}$ & 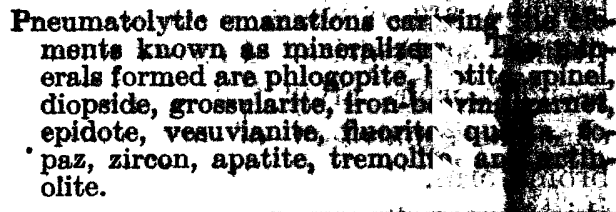 \\
\hline $\mathbf{3}$ & $\begin{array}{l}\text { Igneous roek solid and attacked } \\
\text { by abyssal pneumatolytic } \\
\text { and hydrothermal mana- } \\
\text { tions. The pyrogenetic min- } \\
\text { erals replaced by the new } \\
\text { minerals muscovite, sericite, } \\
\text { chlorite, magnetite (or ilmen- } \\
\text { ite), pyrite, quartz, ore min- } \\
\text { erals, and ankerite. }\end{array}$ & $\begin{array}{l}\text { Abysal pneumatolytic and hydrothermal } \\
\text { emanations formed muscovite, sericite, } \\
\text { chlorite, magnetite (or ilmenite), pyrite, } \\
\text { pyrrhotite, and quartz. }\end{array}$ & 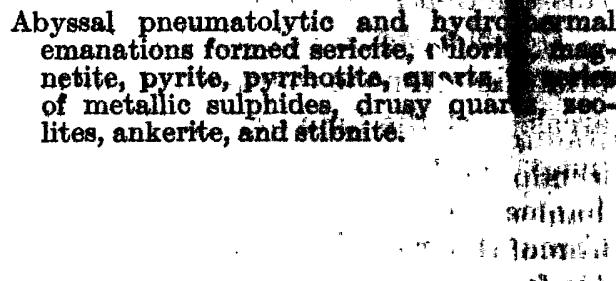 \\
\hline
\end{tabular}

SUMMARY OF THE EVIDENCE THAT THE METAMORPHISM WENT ON IN STAGES

1. The marmarization of the limestone and. recrystallization of the siliceous sediments, with the formation of a sodic plagioclase and an elimination of the original potash mica, preceded the formation of all the other minerals, as shown by the mutual boundary relations and by the uniformly widespread distribution of the minerals formed by the early processes. The rock had been recrystallized to an allotriomorphic aggregate of even grain, and except in zones of most intense metamorphism the grain size is about the same as it was originally.

2. The second stage is represented by minerals the grains of many of which are much larger than those of the first stage and clearly replace them. In the noncalcareous sediments no order of crystallization of minerals of the second stage can be determined, and it is probable that they were in great part contemporaneous. In some of the garnet rocks, however, a definite sequence from pyroxene to amphibole was shown. Many of the minerals formed in the second stage are known to require a high temperature during their formation. The minerals are generally considered to be pneumatolytic, and many required the so-called mineralizers for their formation. The irregular distribution of these minerals in some beds and their grouping into spots and streaks imply that they resulted from solutions that passed through the solid rock with more difficulty than the first solutions.

3. The third stage is the only one whose results are to be found in both exomorphic and endomorphic zones, and this fact suggests that during the eartier stages either the igneous rock "was not yat solid or it was in equilibrium with the solutions that why the metamorphism in the sediments. The latent of of the minerals characteristic of the thi d stemis clearly proved by the boundary reletions bondwe grains. The minerals of the third stage ard fithyst known to be late in most paragenetic seque nces 4 in form at rather moderate temperatures, and period of formation is generally spoken of as hut thermal.

4. The points above given prove that tha mely phism of the sediments was progressive; but thit his stages were to some extent independent of dhe af $1 \mathrm{~h} / \mathrm{g}$ is proved by the finding of many places wer products of one of the stage have formed ithen abundantly than thod of the ofteds, withort apot regard to distivito for contacts. Thu the thes periods must be confidered as overlapping.

tollolat

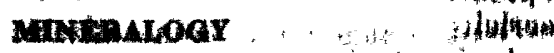
toput

No unusual species were found during the the However, the species represented incluc a proportion of those minerals generally considerct its be commonly due to contact-matamorphic prod Zircon had posaibly pot previously been cnnsident common contect mineral, but the writer lins alphe published the evidence for linowing it to be hell contact mineral and has cited several other nccurrenth reported from contact zones.

:Ititril

At no point were large and well-formed crystaly any of the contact minerals found. In most speciut 
the grains are less than 1 millimeter in diameter, hence necessarily most of the study was made under the microscope. In addition to the examination of about 150 thin sections a considerable number of the specimens were crushed, the grains separated into

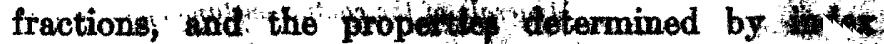
liquids. Thus the constant of most of the minerth were determined trom severral peeimens. The tatue lation that follows may be of interest.

Minerals of the contact-metamorphosed rooks of Pende Greills district, Idaho

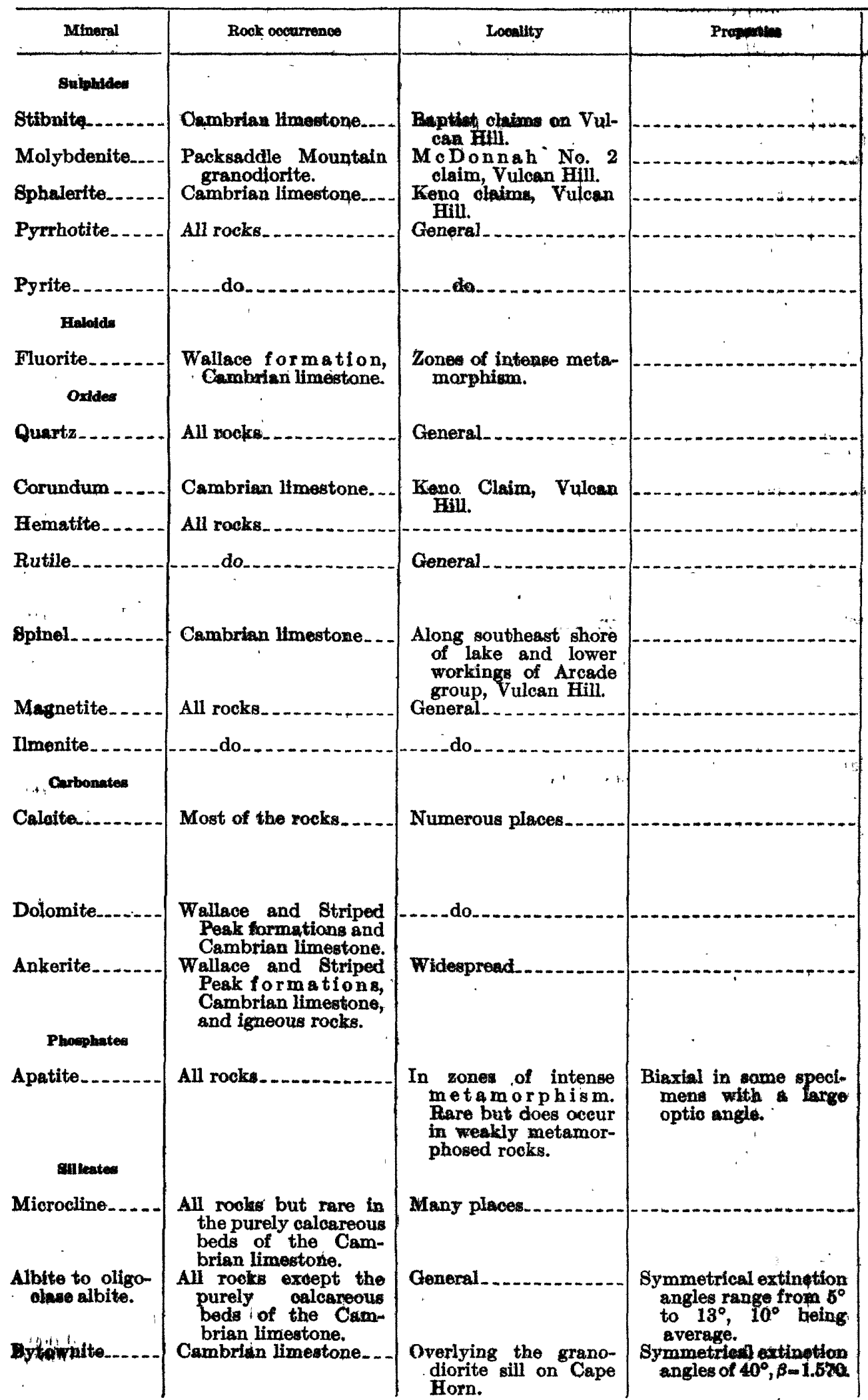

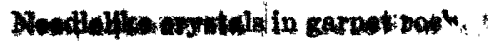
Ir enomonomed zone.

Dleseminotad is limentone and quantity.

Dleweminated in wall anhexial graln: throughout metariorphosed roeks

Drseminated in mall. opyntels throughout metamorphomgd no $\mathrm{ks}$.

Not common. Swen only mirocoopieally and in small quentio of:

Found reint in noncelasm codimant and as a replacer ant mineral is calcareous rocks.

Found in aforowopic oxybtalie in $t$ specimen of an impure limestirne.

Direct fornantion by contect an wh morphism not proved.

In minute quantities where fornd Most ebundant in the metermo phosed Blacktail beds at he mouth Fall Creek. - .

Found in minute green crystal in thin sections of 2 specimens.

$$
\text { ay: }
$$

One of the most widespread minerals due to contact metamorph/ sm. Asocisted with magnetite and $W^{\prime}$ an tifed by chamlcal test.

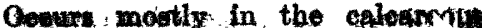
rocks and is thene. due to simble rearyatellization. Also in wh ordinate quantities in a fow ocimens of other rooks.

Minute rhombe widespread in the Waltace formastion and Cumbrist limestone.

Parallibls dolamite in occurrence but found also in velns: On* of the last minetals in the matemorphie sequence.

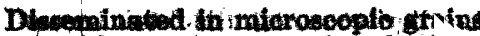
but nowhere: so abundint the albite-aligoelame.

Exceedingty widespread, form to the principal constituent of some edinoles.

Foundin microweopic onymtela at ope place. 
Minerals of the contact-metamorphosed rocks of the Pend Oreille district, Idaho-Continued,

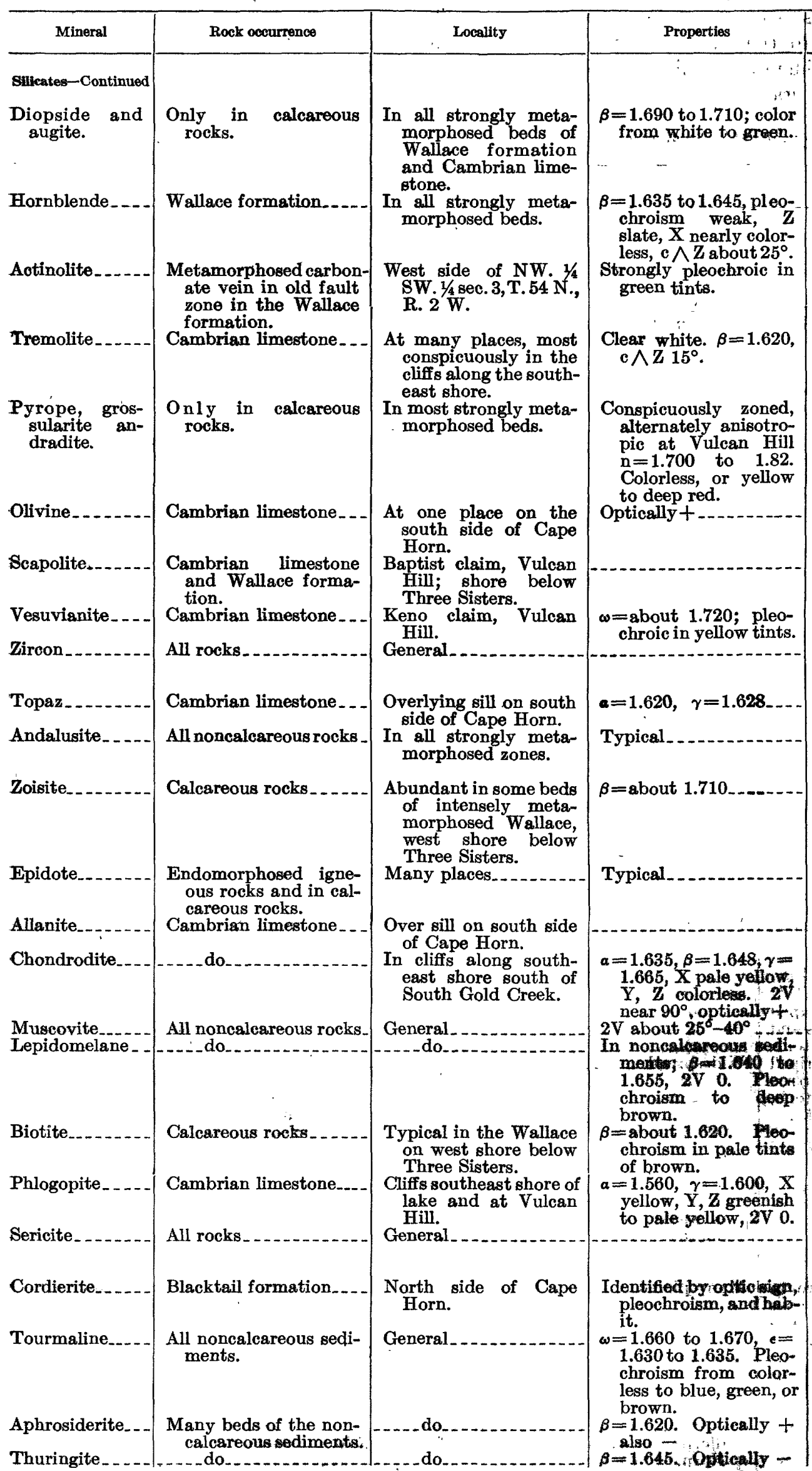

\begin{tabular}{|c|}
\hline Q \\
\hline $\begin{array}{l}\text { Alwaye found in anan andedrons. } \\
\text { In minute prismatic grains, form } \\
\text { ing felted masses. }\end{array}$ \\
\hline
\end{tabular}

Long needlo-hike erystals in quistos:

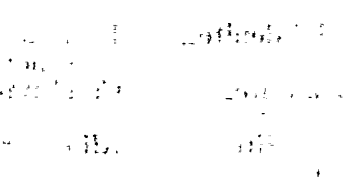

Composition differs markedly in adjacent beds.

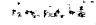

In microscopio erysts ${ }^{1} \mathrm{~s}$, altering to serpentine.

Wernerite, found orly in amall crystals.

Disseminated in mienscopie anhedrons. One large erystal found.

In very minute crystals. See Am. Mineralogist, vol. 10, pp. 187-194, 1925.

Microscopic erystals in one specimen of garnet rock.

In microscopic crystals many of which: were: more or loes aterod to finely divided $\mathrm{m}^{*}$ finkes.
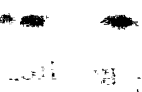

In mieroscopic crystals and anhedrons.

Rave aceessory in on spocinati. :

Common at the ore locally in microseopic cryatals.

Véry widesanead.

Do -

$\because 4$ t

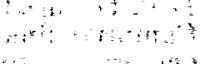

Abundant locally.

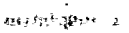

Rare.

$\because 15,4$

Distinguished from museovite by minute size of fikest and be longs to a later ger oration.

Nound in only one spacingeni ${ }^{2}$

A mieroscopic constituent in all moderstely metawn mophosd bods. Absent from severely, mptanuorphosed beds except locally.

Widely distributed especially in the moderately metam rphosed beds.

Do. 
CONTACT METAMORPHISM OF ROCKS IN PEND OREMUL DIBTRIGT, NOANTIEN IDAFO

Minerals of the contact-metamorphosed rocks of the Pend Oreille distict, Idaho-Continued

\begin{tabular}{|c|c|c|c|c|}
\hline Mineral & Rock ocenrrence & Locality & Properties & Alemarks \\
\hline Silicate-Continued & & & & \\
\hline $\begin{array}{l}\text { Antigorite.....-- } \\
\text { Chrysotile...... }\end{array}$ & Cambrian limestone... & $\begin{array}{l}\text { Cliffs along southeast } \\
\text { shore. } \\
\text { Lime quarries at Bay- }\end{array}$ & $\begin{array}{c}\beta=1.555 ; \text { birefringence } \\
\text { weak. } \\
a=1.500, \gamma=1.520\end{array}$ & $\begin{array}{l}\text { In veinlets or as minute mase in } \\
\text { the limestone. } \\
\text { Asbestiform material along sear }\end{array}$ \\
\hline $\begin{array}{l}\text { Heulandite.... } \\
\text { Unidentified ze- }\end{array}$ & do.................... & $\begin{array}{l}\text { Upew. } \\
\text { group Vulit of Arcade } \\
\text { Hill. }\end{array}$ & $\begin{array}{c}a=1.495, \gamma=1.503 .0 p \\
\text { tically }+, 2 \mathrm{~V} \text { small. } \\
n=\text { low. Biref ringence }\end{array}$ & $\begin{array}{l}\text { Crystals in open cavities with an- } \\
\text { kerite. } \\
\text { Found with heulandite. }\end{array}$ \\
\hline Titanite........ & All calcareous rocks. & General_. & $\begin{array}{l}0.015 . \\
\text { Typical }\end{array}$ & $\begin{array}{l}\text { Mioroseopie erystals locally abun- } \\
\text { dant. }\end{array}$ \\
\hline
\end{tabular}

\section{CONCLUSIONS}

The conception that contact metamorphism went on in stages is simply a division of the long-continued process into overlapping periods. The idea of stages in contact metamorphism was perhaps first suggested by Spurr, Garrey, and Fenner ${ }^{6}$ and has subsequently been advanced by several others. Umpleby ${ }^{7}$ used the word "stages" in describing the metamorphism at Mackay, Idaho, and the idea is also expressed in the paragenetic tables of Eckerman. ${ }^{8}$ The descriptions of the Edwards zinc mine by Smyth ${ }^{\circ}$ and by Wade and Wandke ${ }^{10}$ speak of stages in the metamorphism.

The knowledge that contact metamorphism was produced by a long procession of solutions that came out from the igneous rock has succeeded the old idea that it was a simple recrystallization of material already present, caused by the baking heat transmitted by conduction from an adjacent intrusive. This knowledge is of importance not only in itself but also because of the light that it throws upon the process of crystallization of the igneous rocks and the nature of the residual liquids given off during crystallization.

Although contact metamorphism was not a simple recrystallization, this study of the rocks in the Pend Oreille district shows that the nature of the original rock was a very important factor in determining the kind of product resulting from the metamorphism.

o Spurr, J. E., Garrey, G. H., and Fenner, C. N., A contact-metamorphic ore deposit; the Dolores mine, at Matehuala, San Luis Potosi, Mexico: Econ. Geology, vol. 7, pp. 471-474, 1912.

7 Umpleby, J. B., Geology and ore deposits of the Mackay region, Idaho: U. s. Geol. Survey Prof. Paper 97, p. 65, 1917.

8 Eckerman, H. von, The rocks and contact minerals of the Mansjö Mountain: Geol. Fören. Förh., 1922, p. 343.

${ }^{\circ}$ Smyth, C. H., jr., Genesis of the einc ores of the Edwards district, St. Lawrence County, N. Y.: New York Btate Mus. Bull. 201, p. 28, 1917.

${ }^{10}$ Wade, W. R., and Wandke, Alfred, A big zinc mine in New York State: Eng. and Min. Jour. Press, vol, 116, p. 96, 1923.
It shows further that, except very locally, the amount of material introduced permanently was not graat in proportion to the mass of the rock. The parrenetic sequence of the minerals due to contact matamorphism suggests that the progre of crystallization of the igneous rock and the resulting metamorphiam was somewhat as follows:

1. During intrusion and early crystallization of the magma, which marked the first atage, steam carrying soda and some potash was given off in considerrhle quantity from the whole magma and caused the conntry rocks to be recrystallized. Limestones trare turned to marbles, and sericitic quartites and siliceous argillites became adinoles. Connate and surface water played a part in this recrystallization.

2. With the progress of crystallization of the ignenus rock, which marked the second stage, the emanations given off from the residual liquid became richer in the so-called mineralizers. In addition iron, phosphorus, zirconia, and silica, probably magnesia, rare earths, and titanium, and possibly alumina and potash ware also carried. Before this stage was over the ignenus rock was solid at its borders, endomorphic muscorite had formed, and throughout the body of the ignenus rock deuteric titanite, allanite, and probably apatite and zircon had crystallized by replacement.

3. After final consolidation of the main mass of the intrusive which introduced the third stage, when the temperature had become lower, hot waters rich in potash and iron and later in carbon dioxide, sulphur and base and precious metals were given off from greater depths. Sericite, chlorite, and magnetite formed both in the igneous rock and in the sediments and were followed by sulphides, carbonates, and zeolites. 